New Zealand Journal of Industrial Relations, 1982, $7173-178$

\title{
Invisible workers: women, redundancy and unemployment
}

\author{
Mary Hancock*
}

The methods of gathering unemployment statistics in New Zealand effectively render large numbers of women invisible - women who have lost their jobs or are seeking work often do not get recorded as unemployed. The extent of redundancy and unemployment amongst women only begins to become apparent when a range of surveys and industry studies are drawn together. This article reports the results of a study of women made redundant after the Mosgiel closure. The paper reveals the deverstating effect which unemployment has on women's lives.

The extent to which the unemployment burden falls more heavily on women has been partly documented. The provisional results from the 1981 Census show female unemployment rates to be almost one and a half times the male rates (Poot and Brosnan, 1982, Table 3 ) and in the 12 months since the Census was taken we find that the number of women registered as unemployment increased by 1,234 while the number of men registered decreased by 1.834 (NZ Department of Labour, 1982). Registration data tend to undercount unemployed married women since they are not usually eligible for unemployment benefit and are thus less inclined to register. The statistics also undercount the severity of female unemployment on account of the fact that many women rate so lowly their chance of obtaining work that they become "discouraged workers" and do not show up in any official estimates of the unemployed. Several studies have attempted to measure the number of discouraged workers (e.g. Hicks, 1980 and Walsh, 1978) and, despite differing methodologies, they agree that the numbers of female discouraged workers is substantial. A recent preliminary study of the 1981 census results concluded that the number of women discouraged from participating in the work force had increased by at least 9,000 since 1976 (Poot and Brosnan, 1982, p. 28).

Statistics of unemployment are useful in describing the overall pattern of unemployment (subject to the caveats already expressed) but they present only one part of the picture. They hide the dynamics which cause unemployment. Likewise, the role of women as a reserve army of labour is obscured in the aggregate presentation of data. The pattern of factory closures and redundancies in recent years highlights this: the clothing industry a major employer of female labour has lost 14,000 jobs since 1974 . Over 4,000 jobs were lost in the textiles and woollens industry in the single year 1980.

It is often assumed that unemployment and redundancy is felt less severely by women, particularly married women. This is far from true and the rest of this paper examines the hidden effects of unemployment and how traumatic redundancy can be for married women. 


\section{A Study of Women and Redundancy}

In September 1980, 495 workers were made redundant after the collapse and takeover of Mosgiel Ltd - New Zealands's largest textile mill. In a workforce where the male: female ratio was commonly cited at $50: 50$ a far greater number of women were made redundant than men -311 women ( 63 percent) and 184 men ( 37 percent).

In December 1980, the New Zealand Working Women's Council undertook a research project (co-ordinated by the author) to examine the effects of this high job loss amongst women workers at Mosgiel. (Hancock, 1981). The study was carried out on the Melville St Knitwear Division of Mosgiel Ltd in Dunedin, which had not been included in the Alliance takeover deal and which finally ceased production on 19 September 1980. One hundred and twenty-nine staff and employees had been working at Melville St. One hundred (78 percent) were women. Seventy-five of these women were knitwear and make-up workers on the main shift. Between December 1980 and January 1981 the author attempted to locate these 75 women and, by mid January, 62 of the women had been contacted. In this group, 40 (65 percent) were without jobs, 11 had retired involuntarily as there were no jobs available, and 29 were forced back into their homes while they continued seeking work. Only 22 (35 percent) women have been able to get work since the redundancies. On the basis of this information, a representative sample was made and in-depth interviews were carried out with 25 of the women. The material in this paper is drawn from these 25 in-depth interviews and from telephone discussions with the remaining women.

\section{The Effects of Job Loss}

Unemployed women have found that they are grappling with a wide range of difficulties and problems - the key ones being based around the considerable drop in their standard of living, as suddenly their finances become precarious with the loss of wages. Closely associated with these problems and anxieties is the issue of social and psychological well-being. These difficulties are particularly acute for those women who have a young family, or are widowed, seperated or divorced and do not have another major source of income for support. The following case studies (from the Mosgiel research) illustrate the situation that many women face in New Zealand as unemployed workers.

Cathy is married with a young two and a half year old child and is expecting another baby in February. Until she was made redundant in September, she worked full time and brought home an average of $\$ 138$ (including bonus) per week. Her husband brings home $\$ 110$ to $\$ 125$ per week. On their two wages, they could cover all their living expenses and bank $\$ 40$. With Cathy's loss of job, their income has shrunk over 50 percent so that the family must now survive on $\$ 110-\$ 125$ per week plus family benefit and draw on their small savings. As she commented:

my husband's wage is all spent on weekly living and we have nothing left over for power, telephone, insurance, clothes or going out.

Cathy itemized how she budgeted their money each week from this one income:

Food
Husbands work food
Rent
Petrol
Hire Purchase
(washing machine, lawn Mower)
Cigarettes
Cat \& Dog
Total

When she was made redundant she invested her modest redundancy payment. 
But I wish now that I hadn't as my bank account's gone down to nothing. So I'm wondering whether to take it out and use it.

Cathy and her family find it extremely difficult trying to live on this low income. They can can not afford money for clothes, entertainment, weekly bills, and have had to cut back on all purchases, particularly food.

It is very difficult for a family to try and survive on $\$ 20$ per week for food. It worries me living off one wage. It's not much fun. You are limited in what you can do all the time.

After the birth of her second child in February, Cathy plans to find another job.

I would like evening work so I can be home with the children but will settle for anything - perhaps cleaning or waitressing.

The chances of finding such work are remote indeed, e.g. many cleaning jobs advertised in the OtagoDaily Times in January have had over one hundred applicants.

For those women on their own, the hardships that they face are even greater. Many of them have found their incomes dropped by over $\$ 100$ per week when they lost their jobs. In not being able to find alternative work, they have had to rely on a modest benefit.

Jan, who is separated, had two sons living at home. One is unemployed (18 years) and the other is an apprentice (20 years). She is registered as unemployed with the Department of Labour and receives $\$ 52.78$ per week (January) a drop of $\$ 80-90$ per week from her average take home wage and bonus of $\$ 140$ at Mosgiel Ltd. Although her sons contribute $\$ 30$ board, Jan finds that she can only just cover the cost of food. Up until now, she has used her redundancy money to cover bills and expenses but that has now all gone. (Like many other workers she also lost shares in the company - $\$ 1600$ worth).

I can just manage food - but not the bills. The bills will come for the telephone, electricity, coal, DIC account, Smith and Brown account, and TV rental. I don't know how I'll manage once the bills start coming in. There is nothing left for clothes and entertainment.

These women face the horrifying situation of not knowing how they are going to find the money to cope with these financial difficulties. Jobs seem impossible to get and government assistance does not cover the cost of living.

Win is separated and has a 16 year old son (apprentice) living at home, contributing $\$ 20$ per week board. She is on a domestic purposes benefit of just over $\$ 61$ per week (January) - considerably less than the $\$ 166$ per week she had when she worked ( $\$ 150$ clear wages and bonus and $\$ 16$ maintenance that her husband paid her).

It's impossible to live on $\$ 61$ per week. It affects what I can buy and how I feel.

Win has a small amount of savings but this is rapidly disappearing with living expenses and bills.

I had to wait six weeks before I went on to the DPB because of the redundancy money. It was really hard. The money I've got saved is just going - it's not going to last forever - bills have to be paid. I just can't save now and when I actually have to live on $\$ 61$ per week, God help us - it will be impossible.

She has had to cut back on all her purchases. She now buys less of all foods, and buys no clothes at all. She is deeply worried over how she will be able to pay the maintenance bill on her old house.

Frances, a widow, cleared $\$ 150$ per week in her work machining at Mosgiel. She now lives on a widow's benefit of just over $\$ 61$ per week (January) as she has been unable to get another job. This $\$ 90$ per week drop in income has had a major effect on her life.

This is a huge cut in my standard of living. I'm existing and not banking a penny.

I didn't go to the Christmas dinners as I couldn't afford it. I don't have money for any big jobs. What happens if the tube in my TV blows? I don't have the money for extra bills or clothes. 
Her financial difficulties are heightenned by the fact that she lost 2000 shares (in Mosgiel Ltd) and did not receive a redundancy payment because she left before the final closure to seek a permanent job. Frances summed up her distress at the whole situation when she commented:

\section{I can't save for retirement now. It all came too soon.}

The last few months have been problematic for single women as well. Sharon, who has a slight physical disability, has been unable to find another job and is on the sickness benefit. Suzanne, who was helped by Social Welfare ten years ago to find a position in a secure and warm work environment, has been unable to get another job. She is on an unemploy. ment benefit and is just managing to make ends meet with the help of her parents.

For many of the married women who were made redundant and have not been able to find other employment, the last few months have also been difficult. Their households have had to rely solely on their husbands' earnings, which has meant a reduction in income of $\$ 100$ to $\$ 200$ per week (net). This reduction in income has posed considerable problems for these families as frequently both wages were required for reasonable household expenses and daily living.

Irene who used to net an average of $\$ 100$ per week, now finds without her income:

that it's taking an awful lot of adjusting. I found it very difficult to start with, particularly at Christmas, having to cut down. I can't help the kids out now that really affects me.

She now finds that she budgets tightly with food - they go out very little now, and she finds it hard to buy larger items like shoes.

Nola used to average $\$ 155$ per week with bonuses. She lost 1650 shares in the collapse. Now that she has lost her job and as yet has not found another, she finds she has to be very careful with the household budgeting.

We've got to be careful. It's hard having all the family home for meals. We don't see our family as much now as it's expensive to go visiting. I used to clothe my grandchildren, but I can't do it now. We are both struggling, we're having to be careful. I used to like going out but we've had to stop going out now.

Like many others, Nola's fear is for the future.

I'm lucky that my husband's in work. But He's old and has illnesses. If he loses

his job, what's going to happen to us?

Beth and her husband both worked for Mosgiel Ltd. Beth was made redundant in September 1980 and her husband, who works at the Roslyn factory, will probably be faced with redundancy later in the year. Between them, they lost 1800 shares in the collapse. While her husband continues to earn $\$ 150$ per week, Beth is now without a job and wages of $\$ 135-\$ 140$ per week. They are unable to save now and find this particularly disturbing as:

preparing for when we retire has been cut from under us.

As was often stated by the women again and again in the interviews - "we have lost a way of life."

Financial difficulties also face some of the women who did find work after they were made redundant. The new jobs may have lower wages and/or little or no bonus work is available. For example, Eileen's pay packet dropped from $\$ 210$ to $\$ 122$ per week when she finally got her new job. She has four teenage children at home and is now struggling to make ends meet.

I've had to pull my horns in. I can't save at all now. Getting food seems to be taking a lot of my wages and I haven't been buying fruit. I find it hard to contain my grocery bill now.

The women who have been pushed into an early retirement have faced a considerable drop in income and several were quite distressed about the length of time it took for their benfits to commence. 
Women on their own have grave doubts about how they will manage and cope in future. Married women too recognise that things are, and will continue to be, hard. They voice the fear that their worst time is yet to come if their husbands lose work too.

Closely related to the loss of work and the economic problems, worries and anxieties that have emerged is the issue of social and psychological well-being. The majority of these women have been active in the work-force for most of their lives except for the short period of child-rearing when their children were young. So the loss of a job and the lack of possibility of any other work at this time suddenly looms large for these women who frequently commented on the loneliness and boredom of the now "long" hours and days of isolation at home. In response to this, many of them are feeling depressed, tearful and anxious and face little prospect of getting work in the future. As they can not get work, they are increasingly distressed about how to cope.

The fear and worry of not having enough money to "manage on" was shared by many women and is closely linked to their feelings of depression, powerlessness and isolation.

I found it very difficult to start with and used to worry myself sick at night worrying how I'd manage. I want to be doing something, I can't sit at home you feel so useless. Before, life was so organized - now it's so useless. I feel bored - day in day out. I've been feeling depressed it's just awful. Since I've knocked off work, I've gone to the pack. I can't sleep. I'm on sleeping tablets, it's just horrible. I start crying and I can't stop - It's the uncertainty of it all.

These feelings were echoed again and again as was the growing anxiety of facing a cold winter unemployed. In some situations, particularly where women were on their own (widowed, separated or divorced) these worries, anxieties and problems have resulted in severe emotional and psychological ill health and distress, and have lead to some of them seeking medical assistance.

I feel very depressed, life is so empty now. Everytime I go to the shops I wonder how I will cope... Y You lose contract with everyone from work.

Florence, who made these remarks, also spoke at length about how she now gets headaches and feels very weepy. She was going to the doctor next day - she knew that she would be told that the only way to get better was by going back to work - but she hoped she could get some medication to help anyway. The doctor did in fact say that - but as Florence said:

It's easier said than done to get a job in Dunedin now.

For another woman who had done over 40 years of machining work and who lives alone, the news of the receivership and the prospect of loss of her livelihood drove her to look for alternative employment prior to the closure. Her new job, after a soul destroying rigmarole around all the knitwear and machining factories in Dunedin, was hard and nonrewarding.

It was a slave labour camp. He was cutting time - never had time to blow your nose. It was real sweated labour. I was crying and getting near a breakdown. So I went to the doctors - real weepy and depressed.

In this case the doctor prescribed sleeping tablets and pills for depression and, as in the previous example, told her that "she find alternative work" as it was her work situation that was causing the depression and distress. The advice is a bitter pill indeed, in a city with hundreds unemployed, many of whom like herself are skilled workers from Mosgiel.

For many of the married women, a major factor causing feelings of depression, loneliness and isolation was their loss of economic independence as women, and the sudden reliance on their husbands for financial support. Many expressed similar feelings to Pam who commented

It's a knockback losing your independence when you've always earned.

Many women talked at length about these difficulties of dependence and how their husbands could not understand their worry. 
Ann, for example, after three months of unemployment, decided that she had to sell her car, as the money was needed.

It was eating up my money. It was hard, The hardest thing as I'd bought it with my own money, maintained it myself, and the knowledge that I'd never have another one of my own is hard. It was all mine - the only thing that I'd ever had - everything else was a joint thing, whereas the car was mine from my wages. My husband couldn't understand what I was going on about.

This widespread desire amongst the women for economic independence was very aptly shown by Enid. When she was made redundant after 35 years at Mosgiel, she had a gap between the time when her job finished and her superannuation commenced. She did not ask for her husband's pension to be increased to cover her for the period as:

I didn't want to be dependent on him as I've worked all my life.

In the majority of the households, women were providing at least half of the income, and, in many cases, where they were on their own, they were the sole provider. And yet, there is little realisation by their husbands, or society in general of the distress and hardship that results when a woman is suddenly forced into a situation where she loses this financial independence and is then reliant on her husband or a benefit for support. This was particularly evident in situations where the husband and wife have separate bank accounts the unemployed married women must now ask their husbands for money.

\section{Conclusion}

These examples from the women who lost their jobs in the collapse and takeover of Mosgiel Ltd are indicative of the experiences that women have had, and still continue to be faced with throughout the country. There is a recurring theme - of constant tight budgeting and the worry of trying to make ends meet - which emerged from the majority of women who now face financial difficulties through their loss of work and lack of any other forms of employment. In this situation of unemployment, the women are spending considerably less on food, clothing, transport, and entertainment. In most cases they have ceased saving. The social and psychological effects are often quite damaging. More and more female intensive factories and industries are either retrenching or completely closing and laying off their workforce. Redundancy and unemployment have a devastating effect on women's lives and yet little cogniscence is made of this in New Zealand.

\section{References}

Hancock, M. (1981) It just doesn't seem to matter what happens to women Wellington N.Z. Working Women's Council.

Hancock, M. (forthcoming) Women workers and the division of labour, the electronics industry in New Zealand. In K. Clements (Ed) Dominion capitalism: Canada, Australia and New Zealand Christchurch, Cabbage Tree Press.

Hicks, J. (1980) The concept and measurement of hidden unemployment Massey University (mimeographed).

New Zealand Department of Labour (1982) Monthly employment operations March 1982 Wellington.

New Zealand Department of Labour (1980) Women and the workforce Wellington.

New Zealand Department of Statistics (1982) New Zealand Census of Population and Dwellings 1981, provisional statistics, Bulletin 2:National statistics Wellington.

Poot, J. and P. Brosnan (1982) Unemployment and labour force participation : the 1981 census New Zealand population review 8(1):24-34.

Shipley, S. (1982) Women's unemployment Women's Studies Conference Papers '81, Women's Studies Association of New Zealand.

Walsh, C. (1978) Unemployment in New Zealand : an errors in variables approach to measuring the number of unemployed New Zealand economic papers 12:13-46.

Winsome, R. (1980) Textile mill closures and the small town - the case of the Kaiapoi: Woollen Mill 1971-1980 Thesis (B.A. (hons)), Victoria University of Wellington. 